\title{
Cultural Aspects in Andrea Hirata's Novel Sirkus Pohon
}

Asnani, Devi Pratiwy, Safitri Hariani, Pardi, Sri Wulan, and M. Amrin Siregar

Universitas Islam Sumatera Utara (UISU), Medan, Indonesia

\section{Abstract}

This study aims to reveal the cultural aspects of the Belitung Malay community in Andrea Hirata's Novel Sirkus Pohon. The research applied Koentjoroningrat (2000) theory about cultural aspects. The research uses qualitative research which is described in the form of words in the discussion chapter. Qualitative method is used to understand the phenomenon of what is experienced by subjects holistically in a descriptive way in the form of words and languages in a context, especially natural ones by utilizing various natural methods (Moleong, 2010). The cultural elements of Koentjoroningrat (2000) are the source of study, namely aspects of language, knowledge systems, social systems or social organizations, systems of living equipment and technology, living systems, religious systems, and arts. In the discussion, it was found that the seven cultural aspects proposed by Koentjoroningrat are discussed in this study.

Corresponding Author:

Asnani

asnani@sastra.uisu.ac.id

Received: 1 July 2019

Accepted: 18 July 2019

Published: 31 July 2019

Publishing services provided by

Knowledge E

(c) Asnani et al. This article is distributed under the terms of the Creative Commons.

Attribution License, which permits unrestricted use and redistribution provided that the original author and source are credited.

Selection and Peer-review under the responsibility of the AICLL 2019 Conference Committee.

\section{Introduction}

Koentjoroningrat (2000) says that culture means the whole idea and work of human beings that must be accustomed to learning and the whole of character. It is all human power and activities to process, change nature. Whereas culture also belongs to each human being by learning.

Culture is something that lives, develops, and moves towards a certain point (Endraswara, 2013). Culture develops dynamically following developments around it. Studying culture means studying humans in people's lives because culture is born in a society. Endraswara added that cultural studies are basically the study of humans. Culture is the whole activity of life that is lived by humans as individual beings and as social beings (community).

Understanding of culture according to Ki Hajar Dewantara in Koentjoroningrat (2000) is the result of the people's struggle against the state of the times and nature. Culture is also a proof of the prosperity of a society when facing difficulties and obstacles in life. Culture is the result of human struggle by two influences, namely the state of the times 
and nature. Culture is also a proof of man's victory to achieve salvation and happiness whose birth is orderly and peaceful.

Al-Syarqawi in Koentjoroningrat (2000) has a slightly different understanding than experts in general. He views Culture from the view of Islam. According to him, the culture is the history of a group of people reflected in the testimony. There are various values that a life must have meaning and purpose, that are spiritual. So that culture cannot be kept away from the religious values of a tribal community.

\section{Literature Review}

Koentjoroningrat (2000) states that the notion of culture is the whole system of ideas, actions, and results of human work in the framework of people's lives that are made into human property by learning. There are seven elements of universal culture, namely:

\section{Language}

Language is a form of beautiful pronunciation in a culture. As well as being the main intermediary tool for humans in continuing or adapting a culture. Whereas, there are two types of language, namely oral and written language. Generally, tribal people use oral language more often. Because they still have not been able to speak through writing like today's modern society. But they were able to express their feelings through the cave wall pictures. As many found by archaeologist researchers.

\section{Knowledge System}

The next element is a knowledge system that revolves around the knowledge of the surrounding natural conditions, and the nature of the equipment they use. The scope of the knowledge system is in the form of knowledge about nature, flora and fauna, time, space and numbers. The personality of fellow, knowledge systems in culture are formed by the interaction process of each member of the community. In addition, tradition will inherit past knowledge to the younger generation.

\section{Community System or Social Organization}

If a group of people gather in a place with a considerable amount of time, the name of the community will be formed. A group of people can also be called a social organization that has different members, functions and tasks. Community systems include kinship, association, state system, and living unitary system. For a broader meaning it can be interpreted as a nation or even a country, such as Indonesian country. 


\section{Life Equipment and Technology System}

The technology referred the sum of all the techniques possessed by the members of the community. It includes the whole way of acting and acting in relation to raw materials. In addition, processing materials to be made into work tools, storage, clothing, housing, transportation equipment and various other needs. In culture, the most prominent technological element is physical culture. In the form of production equipment, weapons, containers, food and beverages, clothing and jewelry, shelter or houses and transportation equipment.

\section{Living Livelihood System}

The livelihood system is all human endeavors to obtain goods and services that are needed. It can also be called an economic system because it has a close relationship with sufficient living needs. Some types of livelihoods such as hunting, farming, raising livestock and trading. Each region has a distinctive characteristic of a livelihood system. For example, for those living on the coast, they will find fish in the sea. Or people who live in the plantation area will make ends meet by gardening in the fields.

\section{Religious System}

What is meant by religious systems here is a system that is integrated between religious beliefs and behavior. It relates to something sacred and reason does not reach it. The religious system includes, belief systems, values and life views, communication and religious ceremonies. In the community, of course there are religious systems that are so complex from waking to sleeping that there are rules. On the contrary, there are also those that have not been as strict as customary law. But certainly spiritual values greatly influence their way of life.

\section{Art}

Art is defined as all human desires for beauty. Whereas the various forms of beauty emerge from human creative imagination. In addition, of course it can also provide inner satisfaction for humans. There are many arts that are generally produced by a community such as coconut shell crafts, chisels, and many others. To understand art clearly can be mapped into three forms, namely art, sound art and dance.

\section{Research Method}

In observing the cultural aspects of the Belitung Malay community in Andrea Hirata's novel Sirkus Pohon, the authors used qualitative research. According to Moleong (2010), 
qualitative research is research that is used to understand the phenomenon of what is experienced by research subjects holistically in a descriptive way in the form of words and languages in a context, especially natural ones using various natural methods. It can be understood that, qualitative research is a type of research that tries to interpret a problem that arises from a subject using language media which is a natural method for describing these problems.

The data in this study are the sentences in Andrea Hirata's novel Sirkus Pohon, which includes cultural aspects in Belitung Malay community. Seven elements of culture as defined by Koentjoroningrat (2000) becomes a reference in examining existing cultural aspects. The writers select data, identify data, analyze data and present data in sentence form.

\section{Result and Discussion}

In the discussion, the writers apply 7 elements of universal culture according to Koentjoroningrat as a reference in discussing cultural elements in Andrea Hirata's novel Sirkus Pohon.

\subsection{Language}

Andrea Hirata describes the language used in the form of Indonesian oral and written forms. Some of the language activities carried out by the Ketumbi villagers in Andrea Hirata's novel Sirkus Pohon, were carried out orally. For example, when Sobri was accepted to work as a clown in a traveling circus, Sobri conveyed this good news in the form of direct conversation using oral sentences.

"Very good! Where do you work, Bujang?

"Circus!"

Father was stunned.

"What kind of work?"

"Clown!"

Dad got surprised.

"You mean, clown in the circus?"

"Yes! That's my job now, circus clown! "(Hirata, 2017: 60) 
Belitung Malay, in oral conversations, uses many Malay words such as the word 'bujang' which means adult. It is for a son. The father figure in the conversation above did not mention his son's name, Sobri, but used the word 'bujang' instead. In using oral sentences, the Belitung Malay community still uses terms or several Malay words, and mixes it with Indonesian.

Belitung Malay Community in Andrea Hirata's novel Sirkus Pohon also uses beautiful spoken language in the form of pantun. As Malay people, the people of Belitung are able to make pantun orally.

"A lot of walk meet some people.

"Many words long story.

"Instead of just being stunned.

"We better stick to each other."

Not take tempo, I quickly grabbed it.

"Some jokes to rejoice.

"Lift the story from Melaka.

"If you want to laugh, sister.

"Broth brings pomegranates." (Hirata, 2017: 304)

In Andrea Hirata's novel Sirkus Pohon, young people, like Sobri and Suruhudin, are very good at creating and replying to rhymes performed in oral form. The spoken language used is very beautiful by participating in the pantun making process. As it is known th pantun is an old fictional or poetic text consisting of four lines, the first and second lines as sampiran while the third and fourth lines are contents. Pantun usually has certain meanings contained in the contents, namely the third and fourth lines.

The written language variety in Andrea Hirata's novel Sirkus Pohon is in the form of a letter. Tara's letter to Tegar and vice versa.

Tegar,

Good news! Good news! Hurry come home! The circus will be opened again!

This week too! Pack the bag, hurry home, Tegar! (Hirata, 2017: 357)

The above quote is Tara's sentence for Tegar written in the form of a letter. This letter is a personal letter written by Tara which tells of the existence of a circus that has been reopened. 


\subsection{Knowledge system}

The knowledge system revolves around knowledge about the surrounding natural conditions, as well as the nature of the equipment they use. The scope of the knowledge system is in the form of knowledge about nature, flora and fauna, time, space and numbers, the personality of fellow humans, the human body. Knowledge systems in culture are formed by the interaction process of each member of the community. In addition, tradition will inherit past knowledge to the younger generation.

Andrea Hirata's novel Sirkus Pohon, the main character, Sobri, has good knowledge about nature and flora.

Every morning I open the window, I watch the appliance and the other side of the road. When they shake, I know the rainy season is not over. However, this morning I was shocked, I saw that I needed to flank my feet upright like a one-beam army. Kana leaves are glued like gloomy, lemongrass leaves do not move a bit. Then, I saw there, on the branch of the pomegranate, had settled on the east shading season. (Hirata, 2017: 13)

The quote above is Sobri's knowledge of nature. Andrea Hirata expresses it in a good language style. The rainy season is likened to the east shade season. Sobri figures know for sure about nature, such as the season of the plants he saw.

Sobri figures also know well about fauna, such as bird.

I knew them for a long time, and I was able to distinguish the whistling of them, male and female. Before the sun rises, they have whistled. I want to eliminate pomegranates, but I don't have the heart on Diamonds and Diamonds. It is pomegranate tree where they meet first and now where they combine love. (Hirata, 2017: 182)

The above quote illustrates that Sobri really knew two birds from his whistling tone. This illustrates that the knowledge of the bird is obtained from the results of always observing the two birds.

Sobri's knowledge of human personality is also described by Andrea Hirata in Sirkus Pohon.

Hose and stripes, Bro, please let me quote the old Malay proverb. The hose is only a black stain due to being touched by a dirty object, it can be washed. However, crime for Taripol has become its backbone. See the cat, what is the power to wash cat stripes? (Hirata, 2017: 292-293) 
This quote is Sobri's statement because his bicycle was stolen by his best friend, Taripol. He was determined that Taripol would no longer be a good person because it was like a stripe that could not fade even if it was washed or cleaned using anything. Unlike the case with a hose that if exposed to dirty stains can still be cleaned.

The knowledge system in culture is depicted by the character of Tara's mother who has a traveling circus business. His knowledge of the saga of Belitung Malay Community, namely the saga of Raja Berekor, was handed down to the younger generation in the form of a circus drama theater.

Over time, the adaptation of the story of the Malay people of Raja Berekor, originally intended by Mrs. Bos, was only to preserve the local culture through the circus, which turned out to receive a warm welcome from the community. (Hirata, 2017: 162)

One of the preservations of Malay culture in Andrea Hirata's novel Sirkus Pohon is through a circus. The story of Belitung Malay people was appointed as a theater performance like the story of Raja Berekor. The story is about some clowns who fought a tyrant-tailed king. The evil-tailed king is a giant half-ape creature, half an invincible creature. Artifacts such as circuses can be used as cultural preservation tools so that stories or folk stories can be passed on from generation to generation.

\subsection{Community system or social organization}

If a group of people gather in a place with a considerable amount of time, the name of the community will be formed. A group of people can also be called a social organization that has different members, functions and tasks. The social system includes kinship, association, state system, and living unitary system. For a broader meaning it can be interpreted as a nation or even a country, such as this Indonesian country.

In Andrea Hirata's novel Sirkus Pohon, the depiction of the social system was formed in a village called Ketumbi village.

... Aih, his village name is Ketumbi, an ancient Malay word which means 'missed end', 'backward'. In the past, Malay parents who were clever in their minds might be able to see the fate of our village in the future, then give the name of the village that was in accordance with the fold of fate. (Hirata, 2017: 204)

Ketumbi is the name of the village believed by Sobri as a village left behind based on its name. The people of Ketumbi village have long had an organizational system 
such as naming their villages. Just like villages in Indonesia, the community system in Ketumbi village has a family system, a kinship system.

\subsection{Life equipment and technology system}

The technology referred to here is the sum of all the techniques possessed by the members of the community. It includes the whole way of acting and acting in relation to raw materials. In addition, processing materials to be made into work tools, storage, clothing, housing, transportation equipment and various other needs. In culture, the most prominent technological element is physical culture. In the form of production equipment, weapons, containers, food and beverages, clothing and jewelry, shelter or houses and transportation equipment.

In Andrea Hirata's novel, Sirkus Pohon, Tara and her mother are figures who have the ability to create raw materials to be ready to use.

People say she's down his mother's artistic talent. Her mother graduated from an art high school in Yogyakarta, and admitted that, at the same age as Tara now, her abilities far exceeded her. Her daughter drew the decorations of the gypsy trains, designed decorative lights, tents and the main stage. She arranges music, arranges choreography, directs circus theaters, and she is a skilled accordion player. (Hirata, 2017: 62)

Tara and her mother managed and create all the equipment for the circus so that the circus is worth watching. All circus needs are made by themselves.

\subsection{Living livelihood system}

The livelihood system is all human endeavors to obtain goods and services that are needed. It can also be called an economic system because it has a close relationship with sufficient living needs. Some types of livelihoods such as hunting, farming, raising livestock and trading. Each region has a distinctive characteristic of a livelihood system. For example, for those living on the coast, they will find fish in the sea. Or people who live in the plantation area will make ends meet by gardening in the fields.

In Andrea Hirata's novel Sirkus Pohon, the livelihood system of the people varies. Belitung is the largest tin producer in Indonesia. So some residents in Ketumbi village worked as workers in the Tin company. 
My elder brother is a smart person. He is respected in the Department of Technical School Mine PN Timah and is well respected in his work. He served in the PN Timah exploration office. Rank? I don't know, but it's not easy to be employed at the mining frontline unit. The second brother, a quiet surveyor, was also in PN. Speaking a little, always want to be seen as brother. He often gets training to Java. The third brother, employee of the Syahbandar office, has been appointed as a civil servant. (Hirata, 2017: 7)

The quote above is the livelihood of Sobri's brothers. All of them worked as workers in state tin company. They have lived pleasure and more comfortable.

Some people in the novel also have another job, like Sobri's father.

Father always works. Since childhood Daddy has been panning for tin. My father had been a porter in the harbor, filling a sand truck, coconut tree loggers who threatened homes, and well diggers. After having lost strength, Father worked odd jobs in the market and now holds a cash board selling soft drinks at the Belantik Stadium. (Hirata, 2017: 37)

The livelihood of the figure of father in the Sirkus Pohon is the livelihood of most of the Ketumbi villagers. But some also work as police, doctors, bosses, village heads, postal packs, and others.

\subsection{Religious system}

What is meant by religious systems here is a system that is integrated between religious beliefs and behavior. It relates to something sacred and reason does not reach it. The religious system includes, belief systems, values and life views, communication and religious ceremonies.

In the community, there are religious systems that are so complex from waking to sleeping that there are rules. On the contrary, there are also those that have not been as strict as that. But certainly, spiritual values greatly influence their way of life. The setting where the characters in Sirkus Pohon are in a remote village in Belitung, which are generally Malay and they are Muslim. The religious system described in this novel is in the character of Ayah.

The figure of the father is described by Andrea Hirata as a figure who adheres to the guidance of religion. 
God created hands like hands, feet like feet, to make it easier for humans to work. (Hirata, 2017: 37)

The quote above is a message from Sobri's father. This happened when some officers from the village office wanted to attach a sticker that read "Poor House-Village Ladder" on the wall of their home. He politely refused the sticker. In Islam, the life of the world and the hereafter must be balanced. So, working hard for worldly things is also an obligation. This is in the Qur'an, Surat al-Qasas verse 77, "And seek (reward) the Hereafter with what Allah has given you, but do not forget your part in the world and do good (to others) as Allah has done good to you, and do not do damage on earth. Indeed, Allah does not like those who do damage.

\subsection{Art}

Art is defined as all human desires for beauty. Whereas the form of beauty that has a variety of characteristics arises from the creative imagination of humans. In addition, of course it can also provide inner satisfaction for humans.

There is a lot of courage that is generally produced by a community such as coconut shell craft, chisel, and many others. To understand art clearly can be mapped into three forms, namely art, sound art and dance.

The art form in Andrea Hirata's novel Sirkus Pohon is seen in Tara's figure. She learns to paint faces from her mother.

The second exhibition of a 17-year-old young female painter named Tara.

Tara, who will hold her first solo exhibition, showcased 94 of her paintings.

(Hirata, 2017: 165)

Tara has painted over 94 of a face for 8 years. The face painting of the boy who has helped her as child. Using her imagination, she has continued painting his face and change it over time for 8 years, since he was a teenager. Tara painted the faces only by relying on her memories when they were children.

\section{Conclusion}

Andrea Hirata in his Sirkus Pohon revives cultural elements in seven elements of universal culture, namely: language, knowledge systems, social systems and social organizations, living and technological systems, living systems, religious systems and 
arts. These seven elements of universal culture are presented in a mixture of rhythmic words that make this novel worth reading.

\section{References}

[1] Endraswara, Suwardi. (2011). Literature Research Methodology: Epistemology, Models, Theories, and Applications. Yogyakarta: Widyatama Library.

[2] Endraswara, Suwardi. (2013). Anthropology of Literature Research Methodology. Yogyakarta: Waves Publisher (Member of IKAPI).

[3] Hirata, Andrea. (2017). Sirkus Pohon. Yogyakarta: Landscape Publishers.

[4] Koentjoroningrat. (2000). Cultural Aspects. Yogyakarta: Hanindita

[5] _ (2002). Introduction to Anthropology. Jakarta: PT Rineka Cipta.

[6] Moleong, Lexy. J. (2010). Metode Penelitian Kualitatif. Bandung: Remaja Rosda Karya. 